\title{
Effect of vitamin D drops combined with conventional western medicine on children with Type 1 diabetes mellitus.
}

\author{
Jinjun Xue ${ }^{1}$ and Jiacong Xuan ${ }^{2}$ \\ ${ }^{1}$ Department of Paediatrics, Tongde Hospital of Zhejiang Province, Hangzhou City, \\ Zhejiang Province, China. \\ ${ }^{2}$ Department of Pharmacy, Tongde Hospital of Zhejiang Province, Xihu District, \\ Hangzhou City, Zhejiang Province, China.
}

Key words: vitamin D; Type 1 diabetes; helper T-Cells; children.

\begin{abstract}
We investigated the therapeutic effect of vitamin D (VitD) drops, combined with conventional western medicine (insulin), on children with type 1 diabetes mellitus (T1DM). Eighty-four children with T1DM were divided into a routine group and an observation group (42 cases in each group). The routine group was treated with insulin; while the observation group was treated with insulin plus VitD drops. The serum levels of 25-hydroxyvitamin D3 (25(OH)D3) were compared between the two groups before and after treatment. The daily dosage of insulin, time needed for glucose control, two-hour postprandial blood sugar and frequency of episodes of hypoglycemia, were recorded. Flow cytometry was used to detect and compare interferon gamma (INF- $\gamma$ ), interleukin 4 (IL4), and INF- $\gamma / \mathrm{IL}-4$ expression in $\mathrm{CD} 4^{+} \mathrm{T}$ cells of peripheral blood before and after treatment. Complication rates and readmission rates were documented during the six-month follow-ups. VitD drops significantly improved serum vitamin D levels in the routine group $(P<0.05)$. Compared with this group, the daily doses of insulin were lower, the time of blood sugar reaching normal ranges was shorter and the frequency of hypoglycemia was lower in the observation group $(P<0.05)$. There were significant differences in the 2 -hour postprandial blood sugar levels, and flow cytometry results between the two groups $(P<0.05)$. VitD drops combined with insulin are beneficial for blood glucose control of children with T1DM, effectively reducing the insulin utilization rate, reducing the frequency of hypoglycemia, and helping to regulate the Th1/Th2 balance disorder. Complementary treatment with this vitamin is safe and reliable, and can reduce the incidence of complications and readmission rates.
\end{abstract}

Corresponding author: Jiacong Xuan. Department of Pharmacy, Tongde Hospital of Zhejiang Province, Xihu District, Hangzhou City, Zhejiang Province, China. Email: wang.medical23@gmail.com 


\title{
Efecto de gotas de vitamina $D$, combinadas con la medicina occidental convencional, en niños con diabetes mellitus Tipo 1 .
}

\author{
Invest Clin 2021; 62 (2): 159-168
}

Palabras clave: vitamina D; diabetes tipo 1; células T auxiliares; niños.

Resumen. Investigamos el efecto terapéutico de gotas de vitamina D (VitD), combinadas con la insulina de la medicina occidental convencional, en niños con diabetes mellitus tipo 1 (TDM1). Se clasificaron 84 niños con TDM1 en un grupo de rutina y un grupo de observación (42 casos en cada grupo). El grupo de rutina fue tratado con insulina; mientras que el grupo de observación fue tratado con insulina más gotas de VitD. Se compararon los niveles séricos de 25-hidroxivitamina D3 (25 (OH) D3) entre los dos grupos antes y después del tratamiento. Se registraron la dosis diaria de insulina, el tiempo en que se alcanzó el control de la ǵlicemia dentro de rangos normales, la frecuencia de episodios de hipoǵlicemia y la ǵlicemia postprandial a las dos horas. Se utilizó citometría de flujo para detectar y comparar la expresión de interferón gamma (INF- $\gamma$ ), interleucina 4 (IL4) e INF- $\gamma$ / IL-4 en células T CD4 + de sangre periférica antes y después del tratamiento. Las tasas de complicaciones y las tasas de reingreso se documentaron durante el seguimiento de seis meses. Las gotas de VitD mejoraron significativamente los niveles de vitamina $\mathrm{D}$ en suero en comparación con el otro grupo $(\mathrm{P}<0,05)$. En comparación con el grupo de rutina, la dosis diaria de insulina fue menor, el tiempo en que la glucosa en sangre alcanzó un rango normal fue más corto y la frecuencia de episodios de hipoglicemia fue menor en el grupo de observación $(\mathrm{P}<0,05)$. Hubo diferencias significativas en el nivel de glicemia posprandial a las dos horas y los resultados de la citometría de flujo entre los grupos $(\mathrm{P}<0,05)$. Las gotas de VitD combinadas con insulina son beneficiosas para el control de la glucosa en sangre de los niños con DM1, reducen eficazmente la tasa de utilización de insulina, reducen la frecuencia de episodios de hipoglicemia y ayudan a regular el trastorno del equilibrio Th1 / Th2. El tratamiento combinado con esta vitamina es seguro, confiable y puede reducir la incidencia de complicaciones así como la tasa de reingreso.

Received: 16-02-2021 Accepted: 04-04-2021

\section{INTRODUCTION}

Type 1 diabetes mellitus (T1DM) is a kind of autoimmune disease caused by the pancreas islet B cell injury, and T1DM cases take up nearly $5 \%$ to $10 \%$ of the prevalence of DM. Currently, the increase rat of T1DM prevalence has reached about $3.9 \%$ in the world, mainly affecting the teenagers aged between 10 and 14 years old, and bringing about the severe burden on the mental health of children and the family (1). So far, insulin replacement therapy is the major method for T1DM treatment, with exact efficacy, yet still fails to control the blood glucose for some children, or even results in the occurrence of hypoglycemia (2). Evidence from the clinical practice (3) suggests 
that vitamin D (VitD) deficiency is closely correlated with T1DM and autoimmune disease, and VitD is found to regulate the innate immune response and antigen presenting cells (APCs). Furthermore, existing data have suggested that regular administration of VitD is in a positive association with the decreased prevalence of $\mathrm{T} 1 \mathrm{DM}$ in children, while there remains no adequate evidence that suggests the efficacy of co-administration of VitD and insulin on the T1DM pediatric patients. Thus, in this study, we put forward the strategy of co-administration of VitD and insulin in treatment of pediatric T1DM, and compared the resulting efficacy, immune regulation and safety evaluation with the regular strategy, and the results are reported as follows.

\section{SUBJECTS AND METHODS}

General data. A total of 84 children with T1DM, who were admitted to our hospital between January 2013 and April 2020, were recruited into this study and divided into the regular group and the observation group, using a random digit table, with 42 patients in each group. In the regular group, there were 16 boys and 26 girls, aged between 1 and 12 years-old with an average age of $5.90 \pm 1.12$ years, and their average body mass index (BMI) (5) was $21.04 \pm 2.05 \mathrm{~kg} / \mathrm{m}^{2} ; 23$ patients presented positive responses to the antibody test, including eight patients to the GAD65Ab, five positive to the anti-islet cell antibody (ICA), four positive to the anti-insulin antibody (IAA), three positive to IA-2Ab and three positive to GAD65Ab + IAA; 31 patients had complications of diabetic ketosis; as for the clinical manifestations, 22 patients had polydipsia, polyuria, polyphagia and weight loss, ten had fever, eight had vomiting, and 16 had abdominal pain. In the observation group, there were 18 boys and 24 girls, aged between 1 and 12 years-old with an average age of $5.78 \pm 1.10$ years. Their average BMI (5) was $21.11 \pm 2.04 \mathrm{~kg} / \mathrm{m}^{2} ; 24$ patients presented positive responses to the antibody test, including none patients to the GAD65Ab, six positive to the anti-islet cell antibody (ICA), three positive to the antiinsulin antibody (IAA), three positive to IA$2 \mathrm{Ab}$ and three positive to GAD65Ab + IAA; 29 patients had complications of diabetic ketosis; as for the clinical manifestations, 24 patients had polydipsia, polyuria, polyphagia and weight loss, 11 had fever, 7 had vomiting, and 14 had abdominal pain. Comparison of the general data between two groups showed no significant difference (all $P>0.05$; Table I). This study had been approved by the Ethical Board of our Hospital.

\section{Criteria for inclusion and exclusion}

Inclusion criteria: 1) Patients conforming to the diagnostic criteria for T1DM stipulated by the World Health Organization (WHO) $(6)$; 2) patients diagnosed for the first time; 3) patients whose guardians signed the written informed consents. Exclusion criteria: 1) patients who had taken the calcium supplements or related drugs, such as VitD, within two months before admission; 2) patients complicated with infection, trauma or with a surgery history; 3 ) patients who had the complications of severe liver or kidney dysfunction, hyperthyroidism or other diseases of the endocrine system; 4) patients with diseases that potentially affected the levels of VitD in serum, blood glucose, $\mathrm{CD} 4+\mathrm{T}$ cell quantity and Th1/Th2 levels.

\section{Treatment}

Treatment for T1DM complicated with ketoacidosis was conducted as follows: Two venous channels were used - one for rapid infusion of insulin at dose of 0.05 to $1 \mathrm{U} /$ $\mathrm{kg} \cdot \mathrm{h}$ or adjusted according to the blood glucose of patients, while the other was used for fluid infusion to perform the comprehensive treatment; when blood glucose was controlled within 8 to $12 \mathrm{mmol} / \mathrm{L}, 5 \%$ glucose + insulin (2-4 g: $1 \mathrm{U})$ was infused intravenously; for patients with obvious recovery and tolerance to the meals, regular 
TABLE I

COMPARISON OF THE GENERAL DATA BETWEEN TWO GROUPS.

\begin{tabular}{lcccc}
\hline General data & Observation group & Regular group & Statistics & p \\
\hline Sex (n, \%) & $18(42.86)$ & $16(38.10)$ & $0.198^{\mathrm{a}}$ & 0.657 \\
Boys & $24(57.14)$ & $26(61.90)$ & & \\
Girls & $5.78 \pm 1.10$ & $5.90 \pm 1.12$ & $0.495^{\mathrm{b}}$ & 0.622 \\
Age (years) & $21.11 \pm 2.04$ & $21.04 \pm 2.05$ & $0.157^{\mathrm{b}}$ & 0.876 \\
BMI (kg $\left./ \mathrm{m}^{2}\right)$ & & & & \\
Autoantibody (n,\%) & $9(21.43)$ & $8(19.05)$ & $0.074^{\mathrm{a}}$ & 0.786 \\
Positive to GAD65Ab & $6(14.29)$ & $5(11.90)$ & $0.105^{\mathrm{c}}$ & 0.746 \\
Positive to ICA & $3(7.14)$ & $4(9.52)$ & $0.156^{\mathrm{c}}$ & 0.693 \\
Positive to IAA & $3(7.14)$ & $3(7.14)$ & $0.179^{\mathrm{c}}$ & 0.672 \\
Positive to IA-2Ab & $3(7.14)$ & $3(7.14)$ & $0.179^{\mathrm{c}}$ & 0.672 \\
Positive to GAD65Ab+IAA & $24(57.14)$ & $23(54.76)$ & $0.048^{\mathrm{a}}$ & 0.826 \\
Positive to the autonomous antibodies & & & & \\
Clinical manifestations & $24(57.14)$ & $22(52.38)$ & $0.192^{\mathrm{a}}$ & 0.661 \\
Polydipsia, polyuria, polyphagiia & $11(26.19)$ & $10(23.81)$ & $0.063^{\mathrm{a}}$ & 0.801 \\
and weight loss & $7(16.67)$ & $8(19.05)$ & $0.081^{\mathrm{a}}$ & 0.776 \\
Fever & $14(33.33)$ & $16(38.10)$ & $0.207^{\mathrm{a}}$ & 0.649 \\
Vomiting & & & \\
Abdominal pains & & & & \\
\hline
\end{tabular}

${ }^{\mathrm{a}}$ for chi-square test; ${ }^{\mathrm{b}}$ for $t$ test; ${ }^{\mathrm{c}}$ for calibrated chi-square test.

insulin was given subcutaneously prior to meals or sleep, and the dose was adjusted according to the blood glucose, diet or exercise, so as to maintain the blood glucose stable for three months: fasting blood glucose between 4.1 and $7.0 \mathrm{mmol} / \mathrm{L}$, and 2-hour postprandial blood glucose (2hPG) between 7.0 and $10.0 \mathrm{mmol} / \mathrm{L}$.

For patients without ketoacidosis in the regular group, regular insulin was given once prior to the meal or sleep at an initial dose of 0.5 to $1.0 \mathrm{U} / \mathrm{kg} \cdot \mathrm{d}$ adjusted by the diet, exercise and blood glucose to maintain the blood glucose stable for three months.

For those patients in the observation group, they, in addition to the treatment above, received VitD drops (Qingdao Double Whale Pharmaceutical Co., Ltd; State Food and Drug Administration Approval No.: H20113033; Specification: 400 U * 12 cap- sules * three plates) orally (two capsules per day) until the blood glucose was maintained stable for three months.

\section{Observation indexes}

Comparison of the levels of 25(OH)D3 in serum before and after treatment Fasting venous blood $(2 \mathrm{~mL})$ collected from the patients, was left at room temperature and then subjected to centrifugation at $3000 \mathrm{rpm}$ for $10 \mathrm{~min}$, to collect the supernatant and to detect the level of $25(\mathrm{OH}) \mathrm{D} 3$ in serum by using the chemiluminescence immune analyzer and the corresponding kits provided by Roche.

\section{Comparison of the indicators of clinical efficacy}

Before the blood glucose was maintained stable, the daily dose of insulin, time 
needed for glucose control and frequency of hypoglycemia attack were recorded. Moreover, we compared the $2 \mathrm{hPG}$ at the time before treatment, one month later and after treatment between the two groups.

Comparison of the positive rate of $\mathrm{CD} 4+\mathrm{T}$ cells expressing INF- $\gamma$, IL-4 in peripheral blood and the INF- $\gamma /$ IL-4 ratio

Samples of venous blood $(2.5 \mathrm{~mL})$ were drawn from patients before treatment, one month later and after the treatment to isolate the peripheral blood monocyte cells (PBMCs) by using the density gradient centrifugation, and the harvested PBMCs were diluted to a density of $1.0 \times 10^{6} / \mathrm{mL}$ with the RPMI 1640 medium. PBMCs were then stimulated by being incubated with the phorbol ester and monensin, followed by fixation in paraformaldehyde. Surface antigens were labeled by conjugating with the anti-CD4+ antibody, and holes were then made on the surface of cells by the treatment of saponin-diosgenin complex, where the monoclonal anti-INF- $\gamma$ and anti-IL-4 antibodies were added, followed by the detection of positive rate of $\mathrm{CD} 4+\mathrm{T}$ cells expressing INF- $\gamma$, IL-4 in peripheral blood by using the flow cytometry.

\section{Comparison of the incidence of adverse reactions}

Adverse reactions, including the dysfunction of liver or kidney, or anomalies in the biochemical indicators of patients in two groups were recorded during the treatment.

\section{Comparison of the incidence of} complications and re-hospitalization rates between two groups

Follow up was carried out within six months after treatment to record the incidence of retinal lesions, diabetic nephropathy, skin lesions or other complications, and the re-hospitalization rate.

\section{Statistical analysis}

SPSS 24.0 software was used to analyze the data in this study. Measurement data were expressed in form of mean \pm standard deviation $(\bar{x} \pm s)$. For repeated measurements, the difference was validated by the repeated measures analysis of variance, while $L S D$ - $t$ test was adopted to validate the difference between two groups. Enumeration data were described as n (\%), and for the frequency ranging from 1 to 5, calibrated chi-square test was carried out to detect the difference, while for frequency $>5$, chi-square test was adopted. $P<0.05$ suggested that the difference had statistical significance.

\section{RESULTS}

\section{Comparison of the levels of $25(\mathrm{OH}) \mathrm{D3}$ \\ in serum before and after treatment}

Difference of the levels of $25(\mathrm{OH}) \mathrm{D} 3$

in serum before treatment showed no statistical significance $(P>0.05)$, while after treatment, the level of $25(\mathrm{OH}) \mathrm{D} 3$ in the observation group surpassed that of the regular group $(P<0.05)$. Besides, in the observation group, the level of $25(\mathrm{OH})$ D3 after treatment experienced an obvious increase as compared to the level after treatment $(P<0.05)$, while in the regular group, no significant change was found $(P$ $>0.05$; Table II).

\section{Comparison of the clinical indicators between two groups}

In comparison with the regular group, patients in the observation group excelled in the lower daily doses of insulin, shorter time needed to control the blood glucose and a lower frequency of hypoglycemia (all $P<0.05$ ); for $2 \mathrm{hPG}$, the differences between two groups, different time points and interactions showed statistical significance (all $P<0.05$ ), while no significant difference was identified in the 2hPG between the two groups before treatment $(P>0.05)$. One month later and after treatment, $2 \mathrm{hPG}$ in the observation group was lower than that in the regular group $(P<0.05)$, and particularly, 2hPG in two groups was all lower than that before treatment $(P<0.05$; Table III).

Vol. 62(2): 159 - 168, 2021 
TABLE II

COMPARISON OF THE LEVELS OF 25(OH)D3 IN SERUM BEFORE AND AFTER TREATMENT $((\bar{x} \pm s), \mathrm{ng} / \mathrm{mL})$.

\begin{tabular}{cccccc}
\hline Group & $\mathrm{N}$ & Before treatment & After treatment & $\mathrm{t}$ & $\mathrm{p}$ \\
\hline Observation group & 42 & $21.26 \pm 2.14$ & $29.35 \pm 3.12$ & 13.858 & 0.000 \\
Regular group & 42 & $21.11 \pm 2.17$ & $21.46 \pm 2.96$ & 0.618 & 0.538 \\
$\mathrm{t}$ & & 0.319 & 11.889 & - & - \\
$\mathrm{p}$ & 0.751 & 0.000 & - & - \\
\hline
\end{tabular}

TABLE III

COMPARISON OF THE GLINICAL INDICATORS BETWEEN TWO GROUPS $(\bar{x} \pm s)$

\begin{tabular}{|c|c|c|c|c|c|}
\hline \multicolumn{2}{|c|}{ Group } & $\begin{array}{l}\text { Observation } \\
\text { group }\end{array}$ & $\begin{array}{l}\text { Regular } \\
\text { group }\end{array}$ & $\mathrm{t} / \mathrm{F}$ & $\mathrm{p}$ \\
\hline \multicolumn{2}{|r|}{$\mathbf{N}$} & 42 & 42 & & \\
\hline \multicolumn{2}{|c|}{ Daily dose of insulin (U/kg) } & $1.20 \pm 0.21$ & $1.49 \pm 0.32$ & 4.91 & 0 \\
\hline \multicolumn{2}{|c|}{$\begin{array}{l}\text { Time needed to control } \\
\text { the blood glucose (d) }\end{array}$} & $5.20 \pm 0.80$ & $6.41 \pm 1.20$ & 5.437 & 0 \\
\hline $\begin{array}{l}\text { Hypoglycemia } \\
\text { frequency }\end{array}$ & (times/d) & $0.35 \pm 0.06$ & $0.65 \pm 0.12$ & 14.491 & 0 \\
\hline \multirow{3}{*}{$\begin{array}{c}2 \mathrm{hPG} \\
(\mathrm{mmol} / \mathrm{L})\end{array}$} & Before treatment & $7.98 \pm 0.80$ & $7.93 \pm 0.82$ & \multirow{3}{*}{$\begin{array}{c}\mathrm{F}_{\text {intergroup }}=7.028 ; \mathrm{F} \\
\stackrel{\text { time }}{=}=21.289 ; \\
\mathrm{F}_{\text {interaction }}=17.615\end{array}$} & \multirow{3}{*}{$\begin{array}{l}\mathrm{p}_{\text {intergroup }}=0.000 ; \\
\mathrm{p}_{\text {time }}=0.000 ; \\
\mathrm{p}_{\text {interaction }}=0.000\end{array}$} \\
\hline & One month later & $4.79 \pm 0.53^{\mathrm{ab}}$ & $5.52 \pm 0.55^{\mathrm{b}}$ & & \\
\hline & After treatment & $4.81 \pm 0.49^{\mathrm{ab}}$ & $5.54 \pm 0.51^{\mathrm{b}}$ & & \\
\hline
\end{tabular}

Comparison of the positive rates of CD4+T cells expressing INF- $\gamma$, IL-4 and the INF- $\gamma /$ IL-4 ratios in peripheral blood

Statistical significance was indicated in the differences of the positive rates of CD4 + T cells expressing INF- $\gamma$, IL-4 and those of the INF- $\gamma /$ IL- 4 ratios between groups, different time points and interactions (all $P<$ $0.05)$. Prior to the treatment, no significant difference was reported in comparing the positive rates and INF- $\gamma /$ IL- 4 ratios (all $P>$ $0.05)$; one month later, in the observation group, positive rates of $\mathrm{CD} 4+\mathrm{T}$ cells expressing INF- $\gamma$ and INF- $\gamma /$ IL- 4 ratio were all lower than those in the regular group, with a higher positive rate of $\mathrm{CD} 4+\mathrm{T}$ cells expressing IL-4 (all $P<0.05$ ); as the treatment went on, positive rates of $\mathrm{CD} 4+\mathrm{T}$ cells expressing INF- $\gamma$ and INF- $\gamma /$ IL- 4 ratio continued decreasing in two groups (all $P<0.05$ ), while positive rates of $\mathrm{CD} 4+\mathrm{T}$ cells expressing IL-4 increased $(P$ $<0.05$; Table IV).

\section{Comparison of the incidence of adverse reactions}

During the treatment, patients in the two groups had no severe adverse reactions, or anomalies in the functions of liver or kidney.

Comparison of the incidence of complications and re-hospitalization rates

There were no reported cases of complications during the follow up in the observation group, but one patient was rehospitalized due to the fluctuation of blood glucose; patients in the regular group had seven cases of complications, including two cases of retinal lesion, two cases of diabetic 
TABLE IV

COMPARISON OF THE POSITIVE RATES OF CD4 ${ }^{+} \mathrm{T}$ CELLS EXPRESSING INF- $\Gamma$, IL-4 AND THE INF- $\Gamma /$ IL-4 RATIOS IN PERIPHERAL BLOOD ( $\bar{x} \pm s, n=27)$.

\begin{tabular}{|c|c|c|c|c|c|}
\hline \multicolumn{2}{|c|}{ Group } & Observation group & Regular group & \multirow{3}{*}{$\begin{array}{c}\mathrm{t} / \mathrm{F} \\
\mathrm{F}_{\text {intergroup }}=10.186 ; \\
\mathrm{F}_{\text {time }}=22.261 ; \\
\mathrm{F}_{\text {interaction }}=16.526\end{array}$} & \multirow{3}{*}{$\begin{array}{c}\mathrm{p} \\
\mathrm{p}_{\text {interǵroup }}=0.000 ; \\
\mathrm{p}_{\text {time }}=0.000 ; \\
\mathrm{p}_{\text {interaction }}=0.000\end{array}$} \\
\hline INF- $\gamma(\%)$ & $\begin{array}{l}\text { Before } \\
\text { treatment }\end{array}$ & $22.51 \pm 2.83$ & $22.47 \pm 2.59$ & & \\
\hline & $\begin{array}{l}\text { One month } \\
\text { later }\end{array}$ & $17.54 \pm 2.09^{\mathrm{ab}}$ & $19.36 \pm 2.13^{\mathrm{b}}$ & & \\
\hline & $\begin{array}{c}\text { After } \\
\text { treatment }\end{array}$ & $14.32 \pm 1.59^{\mathrm{abc}}$ & $17.12 \pm 1.86^{\mathrm{bc}}$ & & \\
\hline \multirow[t]{3}{*}{ IL-4 (\%) } & $\begin{array}{l}\text { Before } \\
\text { treatment }\end{array}$ & $3.52 \pm 0.31$ & $3.64 \pm 0.33$ & \multirow{3}{*}{$\begin{array}{l}\mathrm{F}_{\text {intergroup }}=13.516 ; \\
\mathrm{F} \\
\mathrm{F}_{\text {time }}=8.516 ; \\
\text { interaction }^{2}\end{array}$} & \multirow{3}{*}{$\begin{array}{c}\mathrm{p}_{\text {intergroup }}=0.000 ; \\
\mathrm{p}_{\text {time }}=0.000 ; \\
\text { pinteraction }\end{array}$} \\
\hline & $\begin{array}{l}\text { One month } \\
\text { later }\end{array}$ & $4.23 \pm 0.49^{\mathrm{ab}}$ & $3.85 \pm 0.55^{\mathrm{b}}$ & & \\
\hline & $\begin{array}{c}\text { After } \\
\text { treatment }\end{array}$ & $5.22 \pm 0.45^{\mathrm{abc}}$ & $4.61 \pm 0.46^{\mathrm{bc}}$ & & \\
\hline \multirow[t]{3}{*}{ INF- $\gamma /$ IL-4 } & $\begin{array}{l}\text { Before } \\
\text { treatment }\end{array}$ & $6.37 \pm 1.06$ & $6.25 \pm 1.12$ & \multirow{3}{*}{$\begin{array}{l}\mathrm{F}_{\text {interǵroup }}=11.896 ; \\
\mathrm{F}_{\text {time }}=25.296 ; \\
\mathrm{F}_{\text {interaction }}=18.417\end{array}$} & \multirow{3}{*}{$\begin{array}{l}\mathrm{p}_{\text {intergroup }}=0.000 ; \\
\mathrm{p}_{\text {time }}=0.000 ; \\
\mathrm{p}_{\text {interaction }}=0.000\end{array}$} \\
\hline & $\begin{array}{l}\text { One month } \\
\text { later }\end{array}$ & $4.12 \pm 0.44^{\mathrm{ab}}$ & $5.25 \pm 0.46^{\mathrm{b}}$ & & \\
\hline & $\begin{array}{c}\text { After } \\
\text { treatment }\end{array}$ & $2.85 \pm 0.51^{\mathrm{abc}}$ & $4.12 \pm 0.55^{\mathrm{bc}}$ & & \\
\hline
\end{tabular}

${ }^{\mathrm{a}} p<0.05$ vs. the regular group; ${ }^{\mathrm{b}} p<0.05$ vs. the level before treatment in the same group; ${ }^{\mathrm{c}} p<0.05 v s$. the level one month later in the same group.

nephropathy and three cases of skin lesions, and eight patients were re-hospitalized due to the fluctuation of blood glucose. Thus, the total incidence rate of complications in the observation group was lower than that in the regular group $(P<0.05$; Table $\mathrm{V})$.

\section{DISCUSSION}

T1DM is a highly complicated T celldominated autoimmune dysregulation, generally caused by the interaction between environmental factors and genetic factors (7-8). T1DM progression involves two stages - inflammation of pancreas and overt diabetes: Inflammation of pancreas is predominantly the persistent injury and apoptosis of pancreas islet $\beta$ cells caused by the infiltration of macrophages and lymphocytes, and when the apoptotic rate of pancreas islet $\beta$ cells surpasses 90\%, disease progresses into the overt diabetes with clinical manifestations of polydipsia, polyuria, polyphagia and weight loss, severely devastating the mental health and life quality of children (9). Previous data (10) support that VitD plays a key role in T1DM pathogenesis via binding to VitD receptor (VDR) which is mainly distributed in the pancreas and $\mathrm{T}$ lymphocytes. VitD, at a low level, can induce the long-term inflammation of pancreas islet $\beta$ cells, thereby affecting the functions to synthesize and secret insulins, or triggering the intolerance to glucose, or decreasing the sensitivity of insulin, eventually contributing to the development of diabetes mellitus.

Results of this study indicated that after treatment, the level of $25(\mathrm{OH}) \mathrm{D} 3$ in serum of patients was higher than that in the regular group, and the such an increase was 
TABLE V

COMPARISON OF THE INCIDENCE OF COMPLICATIONS AND RE-HOSPITALIZATION RATES.

\begin{tabular}{cccc}
\hline Group & $\mathrm{N}$ & $\begin{array}{c}\text { Incidence of complications } \\
\mathrm{n}(\%)\end{array}$ & $\begin{array}{c}\text { Re-hospitalization } \\
\mathrm{n}(\%)\end{array}$ \\
\hline Observation group & 42 & $0(0.00)$ & $1(2.38)$ \\
Regular group & 42 & $7(16.67)$ & $8(19.05)$ \\
Calibrated $\chi^{2}$ & & - & 4.480 \\
$p$ & & 0.018 & 0.034 \\
\hline
\end{tabular}

only found in the observation, instead of the regular group; besides, patients in the observation group excelled in the lower dosage of insulin, shorter time needed to control the blood glucose and a lower frequency of hypoglycemia; one month later and after treatment, $2 \mathrm{hPG}$ of patients in the observation group was lower than that in the regular group, but the positive rate of CD4+T cells expressing IL-4 were higher than that in the regular group. Furthermore, as the treatment went on, $2 \mathrm{hPG}$ in two groups continued to decrease, suggesting that VitD drops in combination with the regular insulin treatment is conducive to the control of blood glucose and reducing the dose of insulin and frequency of hypoglycemia in T1DM patients. As an essential vitamin, VitD is a kind of steroid hormone that is metabolized into the active $25(\mathrm{OH}) \mathrm{D} 3$ which is a major ligand of VDR that is involved in a variety of biological events, including the metabolism of calcium and phosphorus of multiple organs and tissues as well as the cell differentiation and growth (11).

A retrospective analysis of $\mathrm{Wu} \mathrm{M}$ et al. (12) found that VitD supplementation is critical to the T1DM patients. Thus, in their study, regular insulin replacement therapy was combined with the use of VitD drops, and as well as us, found that T1DM patients had a significant reduction in the daily dose of insulin, time needed to control the blood glucose and the frequency of hypoglycemia.

This suggest that VitD level in T1DM patients contributes to the control of blood glucose, which may attribute to the increase of VitD that promotes 25(OH)D3 to bind to the VDR on the surface of pancreas islet $\beta$ cells, thereby regulating the relevant signal pathways to improve the secretion of pancreas islet $\beta$ cells. However, the specific regulation mechanism remains to be validated by the future work.

In addition, we found that one month later and after treatment, positive rate of CD4+T cells expressing INF- $\gamma$ and INF- $\gamma /$ IL-4 ratio were all lower than those in the regular group, with a higher positive rate of $\mathrm{CD} 4+\mathrm{T}$ cells expressing IL-4; as the treatment went on, positive rates of $\mathrm{CD} 4+\mathrm{T}$ cells expressing INF- $\gamma$ and INF- $\gamma /$ IL- 4 ratio continued decreasing in both groups, while positive rates of $\mathrm{CD} 4+\mathrm{T}$ cells expressing IL-4 increased in the observation group; during the treatment, patients in the two groups had no severe adverse reactions, and during the follow-up, the incidence of complications and re-hospitalization rate in the observation group were lower than those in the regular group. Thus, VitD drops in combination with the insulin replacement therapy is conducive to the regulation of Th1/Th2 imbalance in T1DM patients, which is safe and reliable, with the remarkable decreases in the incidence rate of complications and re-hospitalization rate.

Since T1DM is an autoimmune disease, we infer that the effect of VitD on the function of pancreatic islet $\beta$ cells may be realized by the immune regulation, instead of the calcium/phosphorus metabolism. Current evidence (13-14) shows that infil- 
trations of monocytes and cytotoxic lymphocytes are the pathological landmarks of T1DM. T lymphocyte-mediated immune dysregulation causes the left shift in the equilibrium of Th1/Th2, representing the enhancement of Th1 immune response that further increases the secretion of INF- $\gamma$ and antigen presentation, thus strengthening the sensibility of pancreas islet $\beta$ cells to the cytotoxicity and advancing the progression of T1DM. In this study, in addition to the regular supplementation of exogenous insulin, VitD was also taken to regulate the balance of Th1/Th2. According to our analysis, $25(\mathrm{OH}) \mathrm{D} 3$ is able to bind to the VDR on the surface of T lymphocytes, which, therefore, transfers the complex to the VitD reaction element in the promotor of IFN- $\gamma$ to affect the transcription of IFN- $\gamma$ in Th1 cells, thus inhibiting the response of Th1 (15). Moreover, increased 25(OH)D3 contributes to the synthesis and secretion of IL-4, which results in the right shift of Th1/Th2 balance and improves the immune dysregulation of pancreas islet $\beta$ cells. Additionally, patients who underwent the combined strategy had no severe adverse reactions, suggesting that appropriate supplementation of VitD is safe and reliable in treatment of T1DM, and also contributes to the stable control of blood glucose (16).

In conclusion, for pediatric T1DM patients, VitD drops in combination with the regular insulin replacement therapy improves the control of blood glucose, reduces the dose of insulin and the frequency of hypoglycemia, and restore the dysregulated Th1/Th2 balance. Besides, it is safe and reliable in the treatment of T1DM, with a low incidence rate of complications and re-hospitalization rates. However, the conclusion of this study is still limited due to the small sample size that may increase the statistical bias. Thus, in future work, we will expand the sample size and prolong the follow-up to validate the accuracy of this conclusion.

\section{REFERENCES}

1. Dabelea D, Mayer-Davis EJ, Saydah S, Imperatore G, Linder B, Divers J, Bell R, Badaru A, Talton JW, Crume T, Liese AD. Prevalence of type 1 and type 2 diabetes among children and adolescents from 2001 to 2009. JAMA 2014; 311(17):1778-1786.

2. Yan JH, Zhang Y, Zheng XY, Luo SH, Ai HY, Lü J, Qiu LL, Zhang XW, Yang DZ, Yao B, Weng JP. Insulin regimes and impact on glycemic control in patients with type 1 diabetes. Zong yi xue za zhi 2017;97(8):587591.

3. Wang T, Zhang J, Qi FF. Relationship between serum 25(OH)D3 level and islet $\beta$ cell function in individuals with different glucose tolerance. Int J Endo Metabol 2016; 36(4):226-229.

4. Wierzbicka E, Szalecki M, Pludowski P, Jaworski M, Brzozowska A. Vitamin D status, body composition and ǵlycemic control in Polish adolescents with type 1 diabetes. Minerva Endocrinol 2016; 41(4):445-455.

5. Wang XJ, Wang ZH, Dong YH. Comparisons of changes in BMI and waist-height ratio among Chinese Han students from 2010 to 2014. Chin J School Health 2017; 38(6):888-890.

6. Chinese Editorial Board of Guidelines for Diagnosis and Treatment of T1DM. Guidelines for Diagnosis and Treatment of T1DM . Beijing, People's Publish House Co., Ltd 2013:13-15.

7. Censin JC, Nowak C, Cooper N, Bergsten P, Todd JA, Fall T. Childhood adiposity and risk of type 1 diabetes: a Mendelian randomization study. PLoS Med 2017; 14(8):100110.

8. Luo SM, Ma XQ, Zhou ZG. The genetic characteristics of fulminant type 1 diabetes . Nat Med J Chin 2017; $97(8): 561-563$.

9. Wang XJ, Wang T, Yu M. Analysis of clinical characteristics in 12 patients with fulminant type 1 diabetes mellitus. Chin J Diabet 2018; 26(1):69-73.

10. Li Q, Yang Y, Liu BB. Effects of 1, $25(\mathrm{OH})$ ${ }_{2} \mathrm{D}_{3}$ on the content of TG in HepG2 cells and its mechanism. Chin J Diabet 2017; 25(11):57-61. 
11. Wang KX, Zhang J, Ma DL. A Meta-analysis of correlation between vitamin $\mathrm{D}$ and diabetic foot. J Clinic Pathol Res 2017; $37(10): 173-180$.

12. Wu M, Lu JX, Huang Y. Analysis of the correlation between vitamin $\mathrm{D}$ and $\beta$-cell function in type 1 diabetic patients. Chin $\mathrm{J}$ Endocrinol Metabol 2013; 29(10):832-835.

13. Vaseghi $\mathbf{H}$, Jadali $\boldsymbol{Z}$. Th1/Th2 cytokines in Type 1 diabetes: Relation to duration of disease and gender. Ind J Endo Metab 2016; 20(3):312-316.

14. Bao R, Liu, $X$. Research progress of monocyte chemoattractant protein receptor. Chin Bult Life Sei 2006; 18(5): 477.
15. Kuwahara M, Ise W, Ochi M, Suzuki J, Kometani K, Maruyama S, Izumoto M, Matsumoto A, Takemori N, Takemori A, Shinoda K. Bach2-Batf interactions control Th2-type immune response by regulating the IL-4 amplification loop. Nat Commun 2016;7(7):125-130.

16. Bogdanou D, Penna-Martinez M, Filmann N, Chung TL Moran Y, Wehrle J, Badenhoop K. T1lymphocyte and glycemic status after vitamin $\mathrm{D}$ treatment in type 1 diabetes: a randomized controlled trial with sequential crossover. Diabet Metabol Res Rev 2017; 33(3): e2865. 